\author{
Alicja Ortynecka* \\ Jagiellonian University, Poland
}

\title{
Contemporary Love and Pure Relation
}

\section{Preface}

Love as a social phenomenon is described as 'a profoundly tender, passionate affection for another person; strong affectionate relationship; sense of profound link with valuable thing; deep interest in something, finding pleasure in something'

Irving Singer claims that love 'is a form of life, though often short-lived, a disposition, a tendency to respond in a great variety of ways, many overlapping but none that is necessary and sufficient. It is a propensity to have affirmative and corroborative responses, thoughts, and inclinations to act without being limited to any one paradigmatically'2.

Stephen G. Post, Lynn G. Underwood, Jeffrey P. Schloss and William B. Hurlbut find that, at the very core of human love is 'affirmative affection (...) that implies

* ALICJA ORTYNECKA - Graduate of B. A. in Sociology; specializations: Management and Market Research and Public Relations at the Tischner European University in Cracow; Graduate of M. Soc. in Sociology at the University College Dublin;Graduate of postgraduate studies in Project Management at the Tischner European University in Cracow; currently a PhD Sociology student at the Jagiellonian University in Kraków.

1 Słownik Języka Polskiego, Wydawnictwo Naukowe PWN, http://sjp.pwn.pl/haslo.php?id= 2483508 (20.06.2014).

2 I. Singer, Sex: A Philosophical Primer, Oxford 2001, Rowman \& Littlefield Publishers, p. 84. 
benevolence, care, compassion, and action'3. Maslow's hierarchy of human needs locates love and affiliation on the top of the pyramid, arguing that they are as important for every 'social animal' as vitamins for an organism. Sigmund Bauman finds that the constitutive element in shaping human identity is the realization of need of love, through personal relationships. Ann Swidler goes in this contemplation one step further, stating that 'nowadays love aims at individual self-realization"4. Confirmation of individual identity, basing on feeling of loving and being loved, has consequences for the existence in social reality. The way of thinking that an individual is not only an author of his acts, but also simultaneously a 'creator of himself' is well-coordinated with Mead's and Cooley's notion of ego, as a concept of oneself, constructed on the basis of contacts with others. However, even such broad definitions do not exhaust a capacity and multidimensionality of this concept.

In this research, I am focusing on companionate love (often defined as marital love, tender love, affectionate love or true love) which is described as a capacity for 'secure, enduring, and trusting attachment combined feelings of commitment and intimacy ${ }^{5}$. In order to scrutinize the phenomenon more precisely I employ Giddens' theory of pure relation. In his opinion, it is a model of relationships, which is coming to dominate in modern societies of western civilizations. He specifies seven basic elements of pure relation:

1. 'It is not anchored in external conditions of social and economic life;

2. It has unique value due to what it offers to partners;

3. It is a reflexive structured relationship with opened and continuous character;

4. Devotion is a fundamental principle;

5. It is based on intimacy, on which depends stability of a relationship;

6. It demands from partners mutual trust;

7. In pure relation, individual recognizes the other person and in his reactions individual finds confirmation of own identity'.

3 S. G. Post, L. G. Underwood, J. P. Schloss, W. B. Hurlbut, Altruism and Altruistic Love. Science, Philosophy and Religion in Dialogue, New York 2002, Oxford University Press, p. 4.

4 N. Luhmann, Semantyka miłości. O kodowaniu intymności, Warszawa 2003, Wydawnictwo Naukowe Scholar p. 192.

5 N. Luhmann, Semantyka miłości. O kodowaniu intymności, p. 3.

6 A. Giddens, Modernity and Self-identity: Self and Society in the Late Modern Age, Stanford 1991, Stanford University Press, p. 122. 
The aim of this research is to examine the significance of Giddens' theses about pure relation. Does his theory reflect the reality or it is just an unsuccessful attempt at describing it?

Sociologist John Lee constructed a typology of love types. Among twelve love styles we can find: Eros - exclusive relationship based on physical attractiveness; Ludus - a relationship ruled by personal pleasure and fun, in which lovers avoid commitment and monogamy; Storge - a relationship in which mutual love is perceived as a special friendship; Mania - characterizes: conflicted personalities of lovers, dominance of obsession and desire, extremes of jealousy and high demands of affection and commitment from a partner; Pragma - in the foundation of pragmatic relationship lays a rational conviction that all goals can be achieved by personal effort, the beloved is usually the person, which is the most available and compatible to the lover; Agape - a relationship dominated by altruism and devotion, the most idealistic love style, 'rarely found in the real world'7. Alongside classic types, there are also two kinds of mixtures: 'compounds, in which the two ingredients combine to from a genuinely new style and which may have characteristics not shown by either ingredient; or mixtures, which are merely a blending of the two primaries so

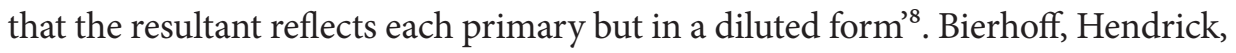
Levy and Davis found out that 'Eros, Agape and Ludus tap variables similar to those making up the major features of romantic love'.

Is pure relation a kind of romantic love? Is it possible to classify Giddens's pure relation in Lee's terms? Taking into account its independence of external conditions, as well as principles of devotion, intimacy and trust, we could perceive it as the Agape. On the other hand, the continuous and open character of a relation would suggest the Ludus. Maybe it is a mixture of these two styles?

\section{Anchors of Pure Relation}

In order to illustrate the presented issue, I constructed schematic graph of pure relation.

7 R. Erber, R. Gilmour, Theoretical Frameworks For Personal Relationships, New Jersey 1994, Lawrence Erlbaum Associates Publishers, p. 193.

8 R. Erber, R. Gilmour, Theoretical Frameworks For Personal Relationships, p. 193.

9 R. Erber, R. Gilmour, Theoretical Frameworks For Personal Relationships, p. 197. 
Graph 1. Schematic graph of pure relation

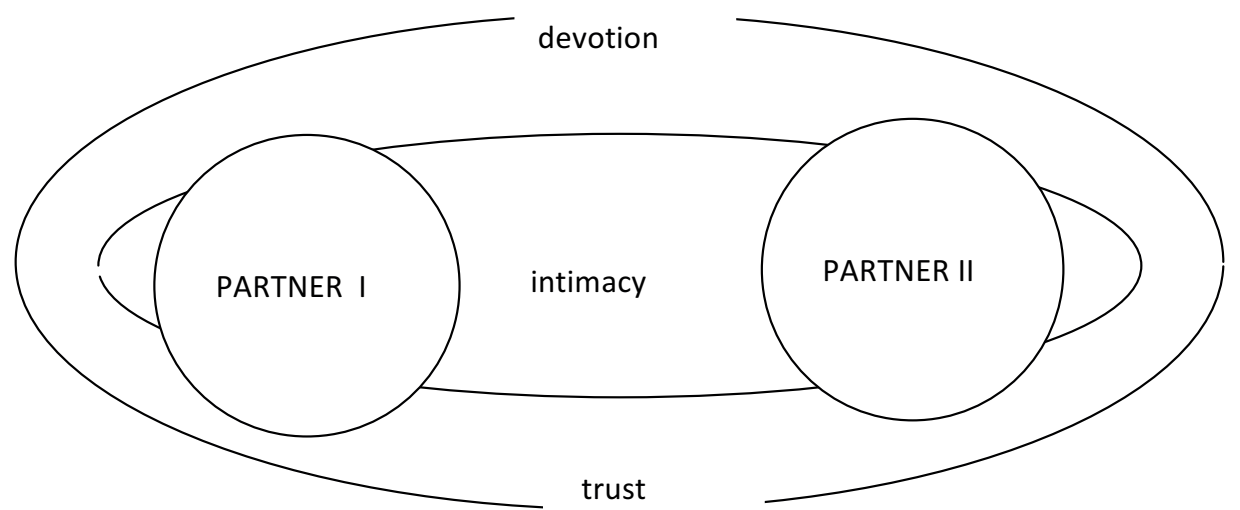

First impressions may remind of Sternberg's Triangular Theory of Love, in which the principal factors of love are: passion, commitment and intimacy. However, Giddens' concept of pure relation is slightly different. The foregoing illustration displays three basic elements: devotion, intimacy and trust which circulate between two partners. The external orbit separates the construction from exterior conditions. Social and economic surroundings play role of mother, which after giving birth to her offspring, gives them living space, where they can develop. Thus exterior structures are not justification and factors that constitute love. Their fundamental roles rely on providing individuals with the conditions for existence. In comparison to her historical forms, modern love is no longer defined in terms of orders and prohibitions. As Giddens describes: 'In pre-modern Europe the majority of marriages was contracted without considering mutual sexual fascination, but for economic reasons ${ }^{10}$. Hatfield and Rapson also state, that earlier marriages were not contracted because of personal happiness and fulfilment, but to serve the well-being of the family and to maintain social order. Nowadays, much research (i.e. Cate and Lloyd, Hatfield and Rapson, Prakasa and Rao, Sprecher and Chandak, Xu and Whyte) shows, that individuals select their partner even despite parental or community objections. Illouz adds that love "began to be represented not only as a value itself but as an important motive in the pursuit of happiness, now defined increasingly in individualistic and private terms"11.

10 A. Giddens, The Transformation of Intimacy: Sexuality, Love and Eroticism in Modern Societies, Cambridge, Cambridge 1992, Polity Press, p. 53.

11 E. Illouz, Consuming The Romantic Utopia, Love and the Cultural Contradictions of Capitalism, London 1997, University of California, p. 30. 
Thus, relationships perceived from this perspective, appear to be autonomous from external conditions of social and economic life. Is it possible? Some of the researchers claim, that none of the human beings can be independent of the influence of previous experiences in attachment relationships. According to the Attachment Theory, past scripts of such relations, especially parent-child style of attachment influence later close relationships in such a manner that the latter resemble one of three general patterns: secure attachment and insecure attachment with two types: avoidant persons and anxious, ambivalent individuals.

Moreover, some scientists emphasize that macro social changes are echoing in microsystems of the social world. Erber and Gilmour find that macro-social forces such as: 'industrialization, and economic change, the pressures toward female equality and the feminization of intimacy as well as the barriers against exit from and entrance into close relationships ${ }^{12}$ have had tremendous influence on contemporary relationships. They present the issue of influences on a personal relationship. Four lens capture four different images of four different but complementary levels: individual (personality characteristic, interpretative filters, goals and behaviors), interpersonal (relationship's atmosphere, its trust, harmony, mutual adjustment and conflict-solving skill), social network and the sociocultural. Furthermore, the authors employing Dutton's Nested Ecological Theory argue that all those levels are highly interrelated, so that we are not able to sharply separate one from the other. Likewise, Kelley highlights the fact that the whole complex of events and interactions between the partners is regulated by broad causal conditions such as: partner's personal characteristics, cumulative properties of the relationship, social and physical environment and links among those elements.

Another argument of existing connections among macro-, exo- and microsystems is given by Dizard and Gadlin, who argue that behind massive social (the erosion of people's dependence on kin and family members) and economic (the spread of commerce and industry) changes, stands the same factor: people's desire for autonomy. Moreover, Berscheid and Campbell distinguished effects on relationships that are caused by contemporary processes of reduction of external (legal, economic, religious, and social) barriers. The first effect relies on a self-driven mechanism: the more people terminate their relationships, the further reductions in social barriers are caused. Secondly, ongoing barrier reductions, increases the emphasis on the sweetness of a relationship's contents. In other words, modern conditions force

12 R. Erber, R. Gilmour, Theoretical Frameworks For Personal Relationships, p. 14. 
partners to constant monitoring and comparing their relationship to whatever they might have elsewhere.

The outcomes of the Cross-Generational Investigation of the Making of Heterosexual Relationships suggest a highly rational nature of a strategy of choosing a partner. The research clearly illustrates, that nowadays, individuals make choices not simply on the basis of sexual attraction or sexual pleasure, but rather they 'form heterosexual relationships according to models of what heterosexual relationships should be like and what characteristics they should have ${ }^{13}$ with special attention paid to reputation and class.

In the light of the presented material on external influences and interrelations existing in the social world, Giddens's thesis of lack of social and economic anchors in a relationship seems to be unrealistic.

\section{Unique value of a relationship}

Giddens' statement, that a relationship is unique due to what it offers to partners, is extremely puzzling. What kind of benefits can be obtained from a close, intimate relationship that cannot be attained anyhow?

Numerous researchers argue that the main function of intimate relationships is replicating a strong affectionate bond as a substitute for parental love. Firestone calls it a 'fantasy bond' ${ }^{14}$, which serves as a self-protective instrument enabling closeness and emotional distance at the same time. He explains the need of creating and maintaining emotional bonds of love due to the egoistic motivation. The author is convinced that the fantasy to be connected is so overwhelming, because it 'denies the inevitability of our personal death and block out the terror of dying ${ }^{315}$. Although it does reflect some elements of Giddens's construct, it also differs significantly. Especially in the assumption that, when "a fantasy bond is formed, individuals prefer to maintain a defensive posture rather than trusting and investing genuine feeling in others"16, while the essence of pure relation is based on trust, intimacy and commitment principle.

13 J. Hockey, V. Robinson, A. Meah, Cross-Generational Investigation of the making of Heterosexual Relationships, http://www.esds.ac.uk/findingdata/snDescription.asp?sn=5190 (10.11.2013).

14 R. Firestone, The Fantasy Bond, New York 1985, Human Sciences Press, p. 5.

15 R. Firestone, The Fantasy Bond, p. 72.

16 R. Firestone, The Fantasy Bond, p. 62. 
The autonomy of pure relation is included in expression "being with each other" instead of traditional love until the end of one's days. A sociological illustration of pure relation's self-sufficiency is Chadwick and Heaton's research on different dimensions and values of a relationship, among which love, as a feeling, came first according to both female and male respondents ${ }^{17}$. Similarly, Buss having interviewed over 10,000 people from 37 countries, found out that, "men and women throughout the world desired much the same things, among which of utmost importance was love!"18 Giddens says that the "individual and the partner become the essence of personal narration deprived of special references to the wider social context ${ }^{\prime 19}$.

At this point we can notice the similarity to Weber's value-orientated action, in which the 'individual unconditionally is guided by its autonomous value ${ }^{20}$. Luhmann expresses it in following way: '(...) It can be postulated, that love should be motivated only by love, that it should refer only to love, that love should look for love, that love should grow up to the extent, in which it can find love and fulfil itself as love ${ }^{21}$. Figuratively referring to the sociological output of neo-functionalism we could interpret love as an autonomous system, which is being reproduced from its own elements and all activities and operations are directed to its interior through constant relevance. These processes take the form of constant exchanges between partners. The essence of pure relation lies in profits that both partners can obtain through a lasting affectionate bond. This tie exists as long as both sides reap benefits from it. Any asymmetry in such an exchange results in lack of stability in relationship. Giddens writes that 'marriage is becoming a relationship created and perpetuated as long as a close contact with the other person is a source of emotional satisfaction ${ }^{22}$.

The achievement of this kind of fulfillment is a challenge; especially nowadays, because 'the bounds of privacy are one of the fundamental elements in a relationship ${ }^{23}$.

17 K. Slany, Alternatywne formy życia małżeńsko-rodzinnego w ponowoczesnym świecie, Kraków 2002, Zakład Wydawniczy NOMOS, p. 157.

18 E. Hatfield, R. L. Rapson, Love and Sex. Cross-Cultural Perspectives, p. 27.

19 A. Giddens, Modernity and Self-identity: Self and Society in the Late Modern Age, p. 55.

20 M. Weber, Pojęcie działania społecznego, in: P. Sztompka, M. Kucia, Socjologia Lektury, Kraków 2005, Znak, p. 60.

21 N. Luhmann, Semantyka miłości. O kodowaniu intymności, p. 33.

22 A. Giddens, The Transformation of Intimacy: Sexuality, Love and Eroticism in Modern Societies, Cambridge, Cambridge 1992, Polity Press, p. 124.

23 A. Giddens, The Transformation of Intimacy: Sexuality, Love and Eroticism in Modern Societies, p. 166. 
Apparently, there is a paradox between mutual intimacy and the requirement of existence of some impassable limits. Conflicts arise because there is a tension between maintaining one's defenses, while at the same time, wishing to hold on to one's initial feelings of closeness and affection.

To decipher the solution for the ideal intimacy, many authors employed many sophisticated logics. Giddens argued that intimacy does not consist in fusion and merging of two personalities, but in recognizing and opening towards the other person $^{24}$. Similarly McAdams described it as 'a basic human need for sharing one's innermost self through closeness and connection ${ }^{25}$. Ruth Sharabany portrayed the notion more precisely. She constructed a definition of intimacy embracing the fundamental principles of pure relation. The inclusive concept consists of eight dimensions: 'frankness and spontaneity (self-disclosure), sensitivity and knowing (empathy and understanding), attachment, the degree of exclusiveness and uniqueness of the relationship, the degree of helping the partner and sharing, the degree of openness and readiness to be vulnerable while being helped, common activities, trust and loyalty ${ }^{26}$.

Simultaneously, autonomy of both partners and close ties between them - these are demands of pure relation. However, Erikson points out that only a mature relationship can 'involve an ability to balance intimacy and independence ${ }^{27}$. In his psychosocial theory of personality development, he specified eight stages in which sixth - intimacy evolves during young adulthood. According to him, a properly developed sense of self and autonomy enables establishing and sustaining long-term, fulfilling, committed relationships, while isolation is the polar opposite. Research conducted by Orlofsky empirically demonstrated his theory, showing that successful personal development in earlier stages affects in mature intimacy. White decided to use continuous scales to rate the maturity of intimacy, which was constituted through commitment, perspective taking and communications. The result of the study was the identification of three basic levels of intimacy: self-focused, role-focused and individuated-connected. On the other hand, Prager distinguishes four characteristic features that sustain intimacy: presence of intimate interactions between the partners, affection, trust and cohesiveness.

24 A. Giddens, The Transformation of Intimacy: Sexuality, Love and Eroticism in Modern Societies, p. 117.

25

D. P. McAdams, Power, intimacy, and the life story: Personological inquiries into identity, New York 1985, New York Guilford Press, p. 57.

26 R. Erber, R. Gilmour, Theoretical Frameworks For Personal Relationships, p. 160.

27 R. Erber, R. Gilmour, Theoretical Frameworks For Personal Relationships, p. 80. 
The most precious thing that the couple is constantly exchanging are "feelings and actions that are not assigned to wider audience"28. Directly connected to that is the next very important element of pure relation: trust, understood as the "conviction or expectation, that the individual will take into consideraton the partner's interests in a process of exchange" ${ }^{29}$, as well as basing activity on that conviction. Contrary to Sternberg's Triangular Theory of Love, in which 'an obligation as a result of conscious decision ${ }^{30}$ is a guarantee of a lasting relationship, in the theory of pure relation it is "trust that is a bet about unsure, future actions" ${ }^{31}$. While trust is only an uncertain project of the future, obligation is a real promise of its realization. Giddens writes that "trust can no longer be anchored in external criteria like kinship, social duty or traditional obligations"32, which factor increases feeling of uncertainty and risk outside the relationship and simultaneously create an asylum inside of it. However, trust can be only achieved, if it involves mutually accepted commitment. Maslow, in his definition of love, emphasizes the role of trust as its inseparable element, and stresses that anxiety cannot rule over relationships. However, how is it possible to generate an engagement and confidence in a relationship, if as Giddens argues, "there is no permanence in human relationships any more than there is in the stock market, the weather, national security, etc."? ${ }^{33}$.

\section{A relation as an exchange}

Luhmann explains the permanence of relationships through the fact, that "individuals are not induced to act, because of anticipated benefit, but because of lack of obviousness of world's project, which is entirely based on individuality of the specific person (...). If generally, we can talk about giving according to love, it

28 A. Giddens, The Transformation of Intimacy: Sexuality, Love and Eroticism in Modern Societies, p. 166.

29 N. Lin, Social Capital: On meaning in everyday life and in sociology, in: M. Maffesoli, The Sociology of Everyday Life, London 2001, Sage, p. 17-30.

30 B. Wojciszke, Człowiek wśród ludzi. Zarys psychologii społecznej, Warszawa 2004, Wydawnictwo Naukowe Scholar, p. 299.

31 P. Sztompka, Zaufanie. Fundament społeczeństwa, Kraków 2007, Wydawnictwo Znak, p. 69.

32 A. Giddens, The Transformation of Intimacy: Sexuality, Love and Eroticism in Modern Societies, p. 6.

33 A. Giddens, The Transformation of Intimacy: Sexuality, Love and Eroticism in Modern Societies, p. 7. 
would mean: letting the other person give oneself" ${ }^{34}$. Lewis considers it similarly saying that, 'the lover desires the Beloved herself, not the pleasure she can give ${ }^{35}$.

Bauman agrees saying that, "love and exchange are located on two opposite ends of continuum containing all interpersonal relations" ${ }^{36}$. Similarly, Georg Simmel finds that the 'technical form of economic transactions create realm of values that are entirely beyond personal-subjective foundation ${ }^{37}$. Lewis argues that 'one of the first things Eros does is to obliterate the distinction between giving and receiving ${ }^{38}$.

If one considers Maslow's words as the truth, that 'love allows to open, cross defensive walls, allows to be physically, psychically and spiritually naked ${ }^{39}$, how can we define vesting both partners with the most precious gift, that they possess - being oneself? Is giving to the partner part of oneself, the most personal form of exchange? Following Simmel we can assume, that people couple because of the rareness of particular goods (needs) and the possibility to obtain them from the partner.

On the contrary, Bauman definitely divides actions into those that have an impersonal character and aim at equivalent exchange and those that are totally disinterested, undertaken regardless of the recipient's character. According to this distinction, there is a division for exchange relations, which are first of all characterized by the principle of equality and for donation relations, in which the central value is sensitivity for another person's needs. The phenomenon of love testifies against this concept: we 'present somebody with a gift' considering - above all - the partner's character. Moreover, I would advance a thesis that it is the partner's uniqueness and unrepeatability, which induces an individual to such an act.

More accurate distinction of forms of exchange is presented by Irving Goffman, who proposes two characteristic types: social and economic. Likewise, Mills and Clark distinguished 'communal relationships, in which members benefit one another on the basis of concern for other's welfare, from exchange relationships,

34 N. Luhmann, 'Semantyka miłości. O kodowaniu intymności', p. 28.

35 C. S. Lewis, The Four Loves: The Much Beloved Exploration of The Nature of Love, Sandiego 1960, Harvest Books, p. 90.

36 Z. Bauman, T. May, Socjologia, Poznań 2004, Zysk i S-ka Wydawnictwo, p. 133.

37 G. Simmel, Wymiana jako środek przezwyciężania czysto subiektywnego znaczenia wartości przedmiotu, in: P. Sztompka, M. Kucia, Socjologia Lektury, Kraków 2005, Wydawnictwo Znak, p. 79.

38 C. S. Lewis, The Four Loves: The Much Beloved Exploration of The Nature of Love, p. 95.

39 A. H. Maslow, The Farther Reaches of Human Nature, http://books.google.com/books/p/pub3330590427236641 ? id=QbPVIsjlQEC\&pg=PA17\&vq=love\&dq=hierarchy+of + needs\&hl=pl\&sig=s SJWucqKbAQwwTnUkKzRE6CXxBg (04.11.2013). 
in which members benefit one another in response to specific benefits received in the past or expected in the future ${ }^{40}$. As mentioned above, researchers believed that romantic relationships belong to communal relationships, or in Goffman's terms: social exchange. These are located on the opposite end to exchange relationships and economic exchange. This kind of relationship is characterized by: 'keeping track of the others' needs even when they cannot help, an inclination to help others and to respond to the others' sadness with increased helping, feeling good about having provided help and welcoming expressions of emotions from the other ${ }^{21}$. This kind of approach appears to have a considerable hint of altruistic character of a relation. However, the authors strictly reject the altruistic nature of communal relationships. They argue that usually beneath a voluntarily-entered mutual relationship, there is a motivation for reciprocation. Thus, on the one hand it could be evidence that selfless behaviors no longer exist and modern world is dominated by instrumental motivations. However, on the other hand, one's hope for reciprocity of his or her feelings can be perceived as a vital foundation of a mutual and caring relationship.

Illouz's research reconciles opposed views, having said that both - erosic and agapic - visions of love exist simultaneously. She argues that a model of mate selection based on a highly rational idea, created from our scrutinized and clarified preferences about the desired attributes of a partner, was found only in the middle-class and upper-middle-class in her sample; whereas among working-class respondents, had different approach to love, which could be described as agapic love. That means love, 'which addresses someone's unique individuality and not his merits ${ }^{32}$ and negates the need of compatibility between partners. Thus, she formulated an hypothesis that 'an agapic conception of love is more likely to be encountered among those for whom marriage does not represent a significant asset in their social position or strategy of mobility, while [...] people most likely to use the rational conceptions of love[...] are upwardly mobile and concerned about maintaining and maximizing their social status ${ }^{43}$.

However, many researchers (Bierhoff, Davis and Latty-Man, Levy and Davis, etc.), examined the relationship between different types of love and satisfaction

40 R. Erber, R. Gilmour, Theoretical Frameworks For Personal Relationships, p. 29.

41 R. Erber, R. Gilmour, Theoretical Frameworks For Personal Relationships, p. 32.

42 E. Illouz, Consuming The Romantic Utopia, Love and the Cultural Contradictions of Capitalism, p. 219.

43 E. Illouz, Consuming The Romantic Utopia, Love and the Cultural Contradictions of Capitalism, p. 220. 
and found out that only Agape and Eros are positively associated with satisfaction, while Pragma is not. If assuming that modern relationships mostly have a nature of Pragma, then satisfaction would not be vital element in the relation. It is one of the reasons, why we are not able to claim a totally rational nature of love. This evidence testifies that, apparently nowadays, we are witnesses of the assimilation of different types of love into one multidimensional structure.

Illouz proposes two main models of love: love as a pleasure, as a fire, as a magnetic force impossible to control and a second one - love as hard work, where relationship is perceived as a contract and partners invest in it in order to reap some benefits. This second type derives from utilitarian individualism, which describes love in terms of costs and satisfied needs. Illouz says that 'the process of mate selection takes the form simultaneously of an exchange of tradable goods and a pooling of resources through the sharing of common tastes, leisure activities and values ${ }^{24}$. First of all, partners, like consumers, can freely choose from a massive pool of possible choices. Secondly, both groups base on the same values: 'aggressiveness, independence, the ability to project one's personality and needs ${ }^{35}$.

Even though it is extremely difficult to speak about measures of love, its analogy to exchange exists. Partner in pure relation, similarly to partner in economic exchange creates a cost and benefit balance. Hatfield's research on equity of inputoutcome ratios between partners confirms the thesis. Her conclusion was that 'relationships tend to last as long as outcome ratios in the relationship are perceived as fair ${ }^{36}$. Moreover, she specified three types of rewards in love relations: personal (having mate who is attractive, sociable and intelligent), emotional (acceptation, understanding, sex, security, etc.) and day-to-day rewards (sociability, comfortable finances, smoother daily routine, etc.) as well as lost opportunities (sexual freedom, money, career, etc.).

Likewise, Parsons argues, that love involves mutual exchange of expressive symbols and the mutual fulfilment of erotic gratifications ${ }^{47}$. Inglis, following

44 E. Illouz, Consuming The Romantic Utopia, Love and the Cultural Contradictions of Capitalism, p. 239.

45 E. Illouz, Consuming The Romantic Utopia, Love and the Cultural Contradictions of Capitalism, p. 194.

46 R. Hatfield. R., J. Traupmann, S. Sprecher, M. Utne, \& J. Hay, Equity and intimate relations: recent research, in: W. Ickes, Compatible and incompatible relationships, New York 1985, SpringerVerlag, p. 362.

47 T. Parsons, The Social System, New York 1951, The Free Press, p. 390. 
Parsons, says 'playing the love game is about successfully sending and receiving messages about our interest ${ }^{48}$.

The exchange theorists' perspective agrees rather well with such a rational view on relationships, having said that 'regardless of type (e.g. friends, lovers or parents and children). relationships are evaluated in terms of ratio of what partners put into them (costs) and what they receive from them (benefits) ${ }^{249}$. Furthermore, partners also evaluate their relationships in terms of comparison level which is 'extent to which they fall above or below their expectations ${ }^{350}$, as well as comparison level for alternatives defined as 'the lowest level of outcomes they will accept in light of what they could get if they terminated their relationship ${ }^{51}$.

It is claimed that the discrepancy between the actual state and the comparison level explains how satisfied partners are in a relationship, while the discrepancy between the actual outcomes and the comparison level for alternatives determines how dependent partners are on a relationship. Moreover, the more the attractiveness of alternatives decreases, the more the level of dependency increases.

Do these outcomes suggest that human beings are instrumental machines looking only for good deals? The Self-Evaluation Maintenance (SEM) model sheds light on the issue of closeness and the egocentric approach. According to the SEM theory, the comparison process is triggered when the person is outperformed on a dimension that is highly relevant to oneself, which in consequence, provokes negative affect, especially if the other is close ('social comparison jealousy ${ }^{52}$ ) and the reflection process elicits positive affect, manifested in feelings of pride for the other.

Interestingly, 'people in close, intimate relationships may not only strive toward maintaining or maximizing their own self-evaluation but also the self-evaluation of the partner ${ }^{53}$. Pilkington's results validated this thesis indicating on two processes: empathic comparison and empathic reflection. These phenomena rely on reporting more activities on which their partner was superior than activities on which self was superior, when the relevance to partner's definition was high, and rating oneself as superior on more activities when relevance to the partner was low. The emergence of this issue suggests that 'relationships in which both partners

\footnotetext{
48 T. Inglis, Sociology of Love, unpublished papers, p. 6.

49 R. Erber, R. Gilmour, Theoretical Frameworks For Personal Relationships, p. 221.

50 R. Erber, R. Gilmour, Theoretical Frameworks For Personal Relationships, p. 221.

51 R. Erber, R. Gilmour, Theoretical Frameworks For Personal Relationships, p. 221.

52 R. Erber, R. Gilmour, Theoretical Frameworks For Personal Relationships, p. 220.

53 R. Erber, R. Gilmour, Theoretical Frameworks For Personal Relationships, p. 215.
} 
strive for excellence on the same performance dimensions will be unstable ${ }^{254}$, because according to the SEM when people are outperformed by their partner on a self-relevant dimension they reduce closeness. This is convincing evidence, that complementarity is a fundamental element of close relationships affecting their stability. On the other hand, it also indicates the highly egocentric nature of human behavior due to the fact, confirmed in many studies, that 'people may alter their behavior to inhibit or facilitate another's performance to reduce possible threats to self-evaluation via comparison or increase opportunities for basking in the reflected glory of the other ${ }^{35}$. Another strategy to avert threats to one's self-evaluation is, also, increasing an effort in an attempt to better one's own performance. To conclude, from the self-evaluation maintenance point of view, individuals, even in close relationships, are guided by self-centered strategies aiming at enhancing one's evaluation either by basking in the reflected glory of the partner if the relevance is low, or by comparison, if the relevance is high.

\section{Egalitarianism?}

Another common element between love relationship and economic exchange is a need of balance among partners, creating either an emotional or economic bond. Argyle and Dean's Equilibrium Theory of Intimacy is a perfect illustration of the importance of a balance in intimate relationships.

On the other hand, sociobiological theories emphasize that men care more about female reproductive capacity, in contrary to women, who care more about the resource acquisition of their partner. Social learning theorists contend the hypothesis of structural powerlessness. They point out that, women generally lack the social, educational and economic means. This fact forces them to look for a mate, who will possess these resources. Simultaneously, the more economic independence possessed by women, the less required are mate's socioeconomic resources. Furthermore, Giddens argues that the degree of prosperity and financial independence is a basis of confluent relations.

Modern social changes create a relationship based on egalitarianism - equal and independent of external conditions engagement of both partners. At the basis of those phenomena are the processes of industrialization and urbanization,

54 R. Erber, R. Gilmour, Theoretical Frameworks For Personal Relationships, p. 215.

55 R. Erber, R. Gilmour, Theoretical Frameworks For Personal Relationships, p. 217. 
heterogeneity and relativity of ethical-moral norms and progressing social atomization. The influence of feminist thought is also inestimable. It redefined the notion of femininity, which so far, had been shaped, basing on fulfilling the maternal role. The woman enabled herself not only through financial independency, higher level of education and consciousness, but also she gave her sex self-dependence. As Illouz shows, 'the less financially dependent women are the more emotional fulfillment rather than economic security they expect from relationship ${ }^{56}$. The roles of man and woman in a relationship started to change. Men have been required to open up for feminine values such as: gentleness, care, understanding and intimacy, while women have been required to remain what they are. Therefore, Illouz confirms Cancian's claim, that romantic love has become feminized ${ }^{57}$. What is feminine has become romantic. As Lawrence Birken argues, 'the nineteenth-century gender division has been erased by an egalitarian ideology of consumers united under the single function of desire ${ }^{58}$.

Nowadays, both sexes are entitled to pursue their personal happiness. Rubin calls it 'the sexual revolution', because it has changed both feminine and masculine perception of sexuality, given space to emotional exchange. On the one hand, it enabled women to experience their natural sexuality, and on the other hand, it gave the possibility for men to have sex among equals, that is, between individuals who made a free choice. A perfect illustration indicating those changes, are the results of Kephart's study, in which thousands of American students were asked 'If a boy/ girl had all the other qualities you desired, would you marry this person if you were not in love with him/her? ${ }^{59}$ While in 1960 s $24 \%$ of women and $65 \%$ of men said that they wouldn't marry him/her, in 1990 s $91 \%$ of women and $86 \%$ of men would not even consider it. Although some researchers argue "that we are living

56 E. Illouz, Consuming The Romantic Utopia, Love and the Cultural Contradictions of Capitalism, p. 49.

57 F. Cancian, Love in America: gender and self-development, Cambridge, Cambridge 1987, University Press, p. 188.

58 E. Illouz, Consuming The Romantic Utopia, Love and the Cultural Contradictions of Capitalism, p. 86.

59 P. Noller, J. A. Feeney, Close Relationships: Functions, Forms and Processes, http://books. google.pl/books?id=OSjL-DTOblEC\&pg=PA238\&dq="if+a+boy/girl+had+all+the+other+qualiti es+you+desired,+would+you+marry+this+person+if+you+were+not+in+love+with+him/her?' \&

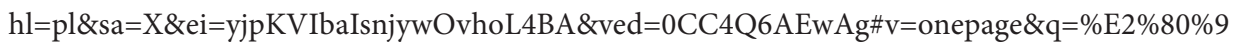
Cif\%20a\%20boy\%2Fgirl\%20had\%20all\%20the\%20other\%20qualities\%20you\%20desired\%2C\%20 would\%20you $\% 20$ marry\%20this\%20person\%20if\%20you\%20were\%20not\%20in\%20love\%20 with\%20him\%2Fher\%3F\%E2\%80\%99\&f=false, p. 238 (20.09.2014). 
in transition between a traditional patriarchal structure and a system that reflects more equality between the sexes"60, from my point of view, the changes towards further women's liberation from male supremacy, partners' multidimensional egalitarianism and gender equality will be gradually increasing.

\section{Mate selection}

Many researchers indicate that "the tie strength between levels of education of the married couple is one of the most explicit characteristic of social structure openness"61. Identical level of education between husband and wife, treated in literature as 'spouses' educational homogamy, exists in more than a half of all European marriages ${ }^{32}$. Moreover, Hatfield, Sprecher, Buss and Rushton notice, that generally "people are most likely to marry those who are similar to themselves in age, ethnic background, socioeconomic status, religion, physical attractiveness, intelligence and education, social attitudes, family size, personality and personal habits" ${ }^{63}$. The phenomenon is explained by attraction, repulsion, necessity or even genetic predisposition (Rushton's Genetic Similarity Theory). Bourdieu proposed very convincible explanations of the phenomenon. He finds that people fall in love with those most readily available to them. In that sense, we could say, that it is not the class, age, education, income, etc. that is a prerequisite of love, but there are some extrinsic conditions that create specified freedom of choice. Bourdieu claims that "a happy love that is a socially approved and success-bound love is the same thing as amor fati, love of one's own social destiny, which brings together socially compatible partners by way of free choice that is unpredictable and arbitrary in appearance only" ${ }^{4}$.

Despite many idealisms, the outcomes of Illouz's research clearly show that choosing a partner for life is still 'a search for a partner with the best available assets

60 C. F. Auerbach, L. B. Silverstein, Qualitative Data - An introduction to coding and analysis, New York 2002, New York University Press, p. 72.

61 H. Domański, D. Przybysz, Homogamia edukacyjna małżonków w krajach europejskich, "Studia Socjologiczne" (2005) 4 (179), p. 89.

62 E. Hatfield, R. L. Rapson, Love and Sex. Cross-Cultural Perspectives, p. 76.

63 E. Hatfield, R. L. Rapson, Love and Sex. Cross-Cultural Perspectives, p. 35.

64 P. Bourdieu, Marriage Strategies as Strategies of Social Reproduction, in: Family and Society, R. Foster, O. Ranum, Baltimore 1972, Johns Hopkins University Press, p. 140. 
and is guided by purposive and utilitarian rationality of the market ${ }^{365}$. Waller's study on college students confirms these findings, concluding that dating among these young people was based on 'highly competitive system of stratification in which students were rated according to looks, popularity, membership in fraternity houses, and so on ${ }^{36}$. The mechanism was very easy: the person who rank highest in all those factors, were considered as most attractive mate. Illouz compares this rational assessment of personal attributes to shopping in the supermarket, when we pick the product that best satisfies our needs and preferences. However, it is worth noting that love mechanisms if associated with market mechanisms, have another vital feature in common. The processes in both spheres run within our consciousness, as well as within our unconsciousness. This characteristic additionally makes them more related. As Erber and Gilmour claim, 'people are aware of such personal decisions, but they are often unaware how the alternatives from which they choose are governed by societal scripts ${ }^{367}$.

Lamont created very useful classification of boundaries in the evaluation of potential partners. He identified three types of barriers: socioeconomic, moral and personality and educational and cultural. Socioeconomic properties of a partner are often described as nice, but unnecessary, probably, because of that, people usually stick to the sacrosanct norm that economic assets do not go along with love. However, when Illouz's respondents were describing their previous relationships, they mentioned, very often, that money played a significant role in the split-up. First of all, money can be a display of our social status, thus they can be a sign of social power. Secondly, spending money for a partner can be viewed as a sacrifice, which is aimed at creating and expressing the romantic bond of commitment. However, again, there is a strong class division. While, middle- and upper-middle-class men were totally for an idea of equitable exchange between man and woman in a relationship, working-class respondents were far less into it. This can be explained through the fact, that alongside the financial dependency they were sustaining, they were also grounding their domination over the woman.

Moral and personality qualities are seen as culturally legitimated factors worth considering when choosing a partner. Here again, the emphasis is laid on different

65 E. Illouz, Consuming The Romantic Utopia, Love and the Cultural Contradictions of Capitalism, p. 197.

66 E. Illouz, Consuming The Romantic Utopia, Love and the Cultural Contradictions of Capitalism, p. 211.

67 R. Erber, R. Gilmour, Theoretical Frameworks For Personal Relationships, p. 2. 
values according to the class. For middle-class respondents, the most important element was 'familiarity with the forms of cultural capital' ${ }^{68}$ (intelligence, originality, creativity, similar lifestyle, ideas and values). What is interesting is that, education, per se, was not the most vital quality, but rather intelligence and ability to discuss ideas. These features not only reflect one's educational capital, but also, they are highly intertwined with one's moral personalities. On the other hand, working-class respondents laid stronger emphasis on the moral features of character needed in order to reliably fulfill his or her role as a parent, provider, husband or wife.

Secondly, Illouz's respondents indicated that the norm of disinterestedness is suspended, when it comes to educational and cultural boundaries. More than half of the upper-middle-class respondents and all the working-class women would not marry someone less educated than themselves. Her conclusion was 'that the downwardly mobile or the 'strained' upwardly mobile respondents for whom marriage was an important factor in achieving a certain social status were the most likely to acknowledge an economically rational approach to love and marriage ${ }^{69}$.

The followingbattery of factors important in a relationship is concerned with communication. Nowadays, its aim is not to seduce or charm, but to express one's thoughts and ideas. Many studies emphasize, that 'communication, self-expression, self-disclosure and verbal intimacy are prerequisites of a successful relationship ${ }^{70}$. It is an important quality especially for upper- and middle-classes first of all, because it provides a good atmosphere for emotional openness and secondly, because it can serve as a mutual assessment of the educational and cultural capital that a person possesses. For the working-class respondents, communication was first and foremost a mean of expressing needs and solving problems, while for the former it, in addition. contained the value of sharing and discussing ideas. Furthermore, women, even from the working class, placed higher value on talking than men. Problems in communication and the reluctance to express their emotions are most often faced by working class men: firstly, because generally men and women follow divergent patterns of socialization; and secondly, men from the working class are inheriting male-centered patterns of communication that they have in their workplaces. Moreover, traditional gender division prominent in working class

68 R. Erber, R. Gilmour, Theoretical Frameworks For Personal Relationships, p. 228.

69 E. Illouz, Consuming The Romantic Utopia, Love and the Cultural Contradictions of Capitalism, p. 232 .

70 E. Illouz, Consuming The Romantic Utopia, Love and the Cultural Contradictions of Capitalism, p. 234. 
households can be caused by the fact - as Marxist scholars argue - that working class men base their sense of worth on their stamina and strength amd that is why emotional sensitivity is seen, by them, as a threat to their virility.

\section{Opened and continuous character of a pure relation}

Slany finds that 'the pure relationship is maintained thanks to acceptance of both sides, that they are obtaining sufficient amount of benefits, to want its persistence ${ }^{71}$. Similarly, Giddens says that the 'reflexive project of self directly refers to benefits, that individual obtains in the relationship and to the pain that she or he can suffer ${ }^{32}$.

He also finds, that confluent love, which links partners in the pure relation, is 'an active and conditional love that clashes with the complex of 'only' and 'forever' of romantic love ${ }^{73}$. Similarly, Bauman points out that. on the one hand. there is a tremendous modern need of being related. but on the other hand, there is a fear of being related for good and forever, which is thought to limit individuals' freedom. He states: 'the romantic definition of love as 'till death us do part' is decidedly out of fashion ${ }^{74}$. Relationships are becoming creative and dynamic products of individuals, which are perceived as risky personal enterprises without social insurance. However, in contrary to Giddens's hypothesis, Hendrick's study reveals that not intimacy, but commitment is the most powerful predictor of breakup, followed by satisfaction, attraction, enjoyment of intimacy, faithfulness and self-esteem. Moreover, Ted L. Huston found a pattern in his research that couples which split up tend to be: 'generally younger, were involved in longer courtships, courtships in which commitment accelerated more slowly and courtships having more downturns in commitment ${ }^{75}$. Thus, the stability of a relationship

71 K. Slany, Alternatywne formy życia małżeńsko-rodzinnego w ponowoczesnym świecie, p. 81.

72 A. Giddens, The Transformation of Intimacy: Sexuality, Love and Eroticism in Modern Societies, p. 127.

73 A. Giddens, The Transformation of Intimacy: Sexuality, Love and Eroticism in Modern Societies, p. 80 .

74 Z. Bauman, Liquid Love. On the Fragility of Human Bonds, Cambridge 2003, Polity Press, p. 5.

75 R. Erber, R. Gilmour, Theoretical Frameworks For Personal Relationships, p. 60. 
appears to be moderated by age, commitment and - what Davis, Kirkpatrick, Levy and O'Hearn discovered - also by 'gender and type of attachment ${ }^{76}$.

Furthermore, Slany claims that we have to do with a new discourse on love, which is an 'elastic and dynamic feeling, which has its beginning and quite fast appearance of an end ${ }^{177}$. An individualistic attitude favors treating the other person as a partner, as long as he meets an obligation of exchange. Similarly, Giddens finds that the current image of a relationship is just a consequence of a different model of love, which nowadays is strongly connected to human carnality and sexuality. His thesis, that 'sexuality is so important, that it is becoming the element of reflexive project of individual's identity' is clearly inspired by Foucault, who states, that "we live in society of sex"78. According to their perspective, it enables not only self-fulfillment, but also gaining and expressing our intimacy. Similarly, Inglis says that 'understanding love, passion and desire is central to understanding who and what we are ${ }^{\text {'79 }}$. Likewise, Zoldbrod defines sexuality as 'a dimension of personality instead of referring to a person's capacity for erotic response alone ${ }^{80}$. Moreover, it is emphasized that 'most modern societies are moving in the direction of allowing greater sexual freedom for all individuals ${ }^{31}$.

Professor Slany goes one step further, conditioning quality and stability of relationship to sexual life. The autonomous and impersonal sexual sphere becomes an exceptional form of activity. Evans agrees with the saying that 'what has changed it not the nature of sexual activity, but our willingness for its public recognition and discussion $^{\text {'82 }}$. Luhmann goes on to say, that consciousness of individual person as well as consciousness of one's love is gained through public approval. Nowadays, conjugal life not necessarily demands such a social legitimization like marriage. Demonstrating consent to premarital sexual life, contraception, lowering age sexual initiation, and tremendous diversity of sexual behaviors assimilates modern love to Eros and Ludus, which aim at pure satisfaction without any responsibility. 'Sex

76 R. Erber, R. Gilmour, Theoretical Frameworks For Personal Relationships, p. 190.

77 K. Slany, Alternatywne formy życia matżeńsko-rodzinnego w ponowoczesnym świecie, p. 99.

78 A. Giddens, The Transformation of Intimacy: Sexuality, Love and Eroticism in Modern Societies, p. 96.

79 T. Inglis, Lessons in Irish Sexuality, University College Dublin Press, 1998, p. 8.

80 A. P. Zoldbrod, Men, women, and infertility: intervention and treatment strategies, New York 1998, Lexington Books, p. 2.

81 E. Hatfield, R. L. Rapson, Love and Sex. Cross-Cultural Perspectives, p. 151.

82 M. Evans, Love An Unromantic Discussion, Cambridge 2003, Polity Press, p. 91. 
is now expected to be self-sustained and self-sufficient, (...) to be judged solely by the satisfaction it may bring on its own'83. According to Ira Reiss's typology

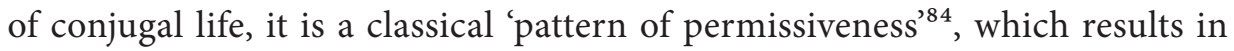
sex without emotions. On the contrary, Luhmann thinks that, sexual relations enable creating truly intimate personal relationships, thanks to the reflexivity of reciprocal desire, which excludes cost and benefit calculations. I would postulate for Wouters's perspective, which sees modern relationships as consisting ttwo main interests: maintaining long-term loving relationships and pure sex, what he calls the 'love-lust balance ${ }^{85}$.

Carlson, believing that sexuality became a part of people's intimate understanding of themselves, proposed a very interesting typology of discourses about sexuality. Among four of them, two - a libertarian discourse and radical Freudian discourse - seem to be most accurate picture of modern sexuality in Giddens' categories. The first one is centered on an ethic of reciprocity and consensus - the basic norms of pure relation. Moreover, Seidman points out that a liberal discourse revolves around two fundamental changes: 'the sexualisation of love and the eroticization of $\operatorname{sex}^{86}$ - phenomena, which are also indicated by Giddens. The latter discourse bases on the Freudian perspective, in accordance to which, modern human beings quell the sexual impulse and replace it with a more general, platonic type of love, because of constant oppression and alienation of social relations. Ann Swidler explains it more precisely: 'making love meant (...) learning to see and appreciate the others, particularly those with whom one made love, not as a love object to be owned and possessed, but as a source of beauty, understanding and self-realization ${ }^{287}$. As Sanford describes ' $(. .$.$) real love begins only when one person comes to know another for$ who he or she really is as a human being $(\ldots)^{\prime 88}$. The basis of self-reflexivity in pure relation is the concept of a relationship as a mirror in which we can once again

83 Z. Bauman, Liquid Love. On the Fragility of Human Bonds, p. 45.

84 E. Hatfield, R. L. Rapson, Love and Sex. Cross-Cultural Perspectives, p. 98.

85 C. Wouters, Sex and Manners: Female emancipation in the West 1890-2000, London 2004, Sage, p. 128.

86 S. Jackson, S. Scottp, Gender: A Sociological Reader, Routledge Student Reader, London 2002, p. 71 .

87 A. Swidler, Culture in Action: Symbols and Strategies, "American Sociological Review" 51 (1986), p. 275.

88 J. A. Sanford, The invisible partners: how the male and female in each of us affects our relationships, New York 1980, Paulist Press, p. 88. 
see the other, but also ourselves. The only thing which varies Carlson's radical discourse from Giddens' view, is how sexuality is performed by an individual. From the Carlson's point of view, there is a need of fundamental changes in the organization of social life (concerning work, leisure, gender relations, economy, etc.). On the contrary, Giddens finds that the capitalistic system and modernity are inseparable elements of the process of liberating an authentic sexuality.

\section{Conclusions}

I strongly disagree with Beck's thesis of constant and disorderly 'chaos of love'. Even though particular behaviors of a loving individual can be seen as irrational and chaotic, the interests and expectations are very well estimated. Moreover, love equips a human, as a member of society, with priceless instruments. As Inglis argues, 'the accumulation of love capital can help the attainment of other forms of capital in other social fields ${ }^{89}$. The individual learns all that is elementary for a correctly functioning society. Probably, that is why Giddens says, that 'a chance for intimacy is at the same time a chance for democracy ${ }^{90}$. In this process, a decisive role is played by autonomy, which allows us to properly estimate other people's potential. To conclude, love has a tremendous weight not only within the functioning of the individual, but it also directly or indirectly influences the form and essence of social life.

The presented literature answered many of the previously posed questions. According to existing research, contemporary love resembles a mixture of Pragma and Ludus with a hint of Agape. The theoretical background successfully deprived Giddens the right to claim that contemporary relationships are pure relations. In my opinion, a weak point of his theoretical thinking is the fact, that it is very imprecise and unsystematic. Gathered material testifies, that, contrary to his hypotheses: relationships are anchored in external conditions of social and economic life. Moreover, apart from devotion, there are also other principles thought as fundamental values, and that the stability of a relationship depends on more factors than just on intimacy.

89 T. Inglis, Lessons in Irish Sexuality, p. 12.

90 A. Giddens, The Transformation of Intimacy: Sexuality, Love and Eroticism in Modern Societies, p. 222. 
However, the issue still provokes puzzling questions about the nature of love and relationships. What elements constitute the phenomenon? What kind of unique values does the relationship offer? Is it possible to capture the logic of infatuated individuals?

\section{Bibliography}

Auerbach C. F., Silverstein L. B., Qualitative Data - An introduction to coding and analysis, New York 2002, New York University Press.

Bauman Z., May T., Socjologia, Poznań 2004, Zysk i S-ka Wydawnictwo.

Bourdieu P., Marriage Strategies as Strategies of Social Reproduction, in: Family and Society, R. Foster, O. Ranum, Baltimore 1972, Johns Hopkins University Press, p. 140-178.

Cancian F., Love in America: gender and self-development, Cambridge, Cambridge 1987, University Press.

Domański H., Przybysz D., Homogamia edukacyjna małżonków w krajach europejskich, "Studia Socjologiczne" (2005) 4 (179), p. 84-110.

Erber R., Gilmour R., Theoretical Frameworks For Personal Relationships, New Jersey 1994, Lawrence Erlbaum Associates Publishers.

Evans M., Love An Unromantic Discussion, Cambridge 2003, Polity Press.

Firestone R., The Fantasy Bond, New York 1985, Human Sciences Press.

Giddens A., Modernity and Self-identity: Self and Society in the Late Modern Age, Stanford 1991, Stanford University Press.

Giddens A., The Transformation of Intimacy: Sexuality, Love and Eroticism in Modern Societies, Cambridge, Cambridge 1992, Polity Press.

Hatfield R., Traupmann J., Sprecher S., Utne M., \& Hay J., Equity and intimate relations: recent research, in: W. Ickes, Compatible and incompatible relationships, New York 1985, Springer-Verlag. Hockey J., Robinson V., Meah A., Cross-Generational Investigation of the making of Heterosexual Relationships, http://www.esds.ac.uk/findingdata/snDescription.asp?sn=5190 (10.11.2013).

Illouz E., Consuming The Romantic Utopia, Love and the Cultural Contradictions of Capitalism, London, 1997, University of California.

Inglis T., Lessons in Irish Sexuality, University College Dublin Press, Dublin 1998.

Inglis T., Sociology of Love, unpublished papers.

Jackson S., Scott S., Gender: A Sociological Reader, Routledge Student Reader, London 2002.

Lewis C. S., The Four Loves: The Much Beloved Exploration of The Nature of Love, Sandiego 1960, Harvest Books.

Lin N., Social Capital: On meaning in everyday life and in sociology, in: M. Maffesoli, The Sociology of Everyday Life, London 2001, Sage, p. 17-30. 
Luhmann N., Semantyka miłości. O kodowaniu intymności, Warszawa 2003, Wydawnictwo Naukowe Scholar.

Maslow A. H., The Farther Reaches of Human Nature, http://books.google.com/books/p/ pub-3330590427236641 id=QbPVIsjlQEC\&pg=PA17\&vq=love\&dq=hierarchy+of + needs \&hl=pl\&sig=sSJWucqKbAQwwTnUkKzRE6CXxBg (04.11.2013).

McAdams D. P., Power, intimacy, and the life story: Personological inquiries into identity, New York 1985, New York Guilford Press.

Noller P., Feeney J. A., Close Relationships: Functions, Forms and Processes, http://books.google. $\mathrm{pl} /$ books?id=OSjL-DTOblEC\&pg=PA238\&dq="if + a+boy/girl+had+all+the+other +quali ties+you+desired,+would+you+marry+this+person+if+you+were+not+in+love+with+h $\mathrm{im} /$ her?' \&hl=pl\&sa=X\&ei=yjpKVIbaIsnjywOvhoL4BA\&ved=0CC4Q6AEwAg\#v=onepage \&q=\%E2\%80\%9Cif\%20a\%20boy\%2Fgirl\%20had\%20all\%20the\%20other\%20qualities\%20 you $\% 20$ desired $\% 2$ C $\% 20$ would $\% 20$ you $\% 20$ marry\%20this\%20person $\% 20$ if $\% 20$ you $\% 20$ were\%20not\%20in\%20love\%20with\%20him\%2Fher\%3F\%E2\%80\%99\&f=false (20.09.2014).

Parsons T., The Social System, New York 1951, The Free Press.

Post S. G., Underwood L. G., Schloss J. P., Hurlbut W. B., Altruism and Altruistic Love. Science, Philosophy and Religion in Dialogue, New York 2002, Oxford University Press.

Sanford J. A., The invisible partners: how the male and female in each of us affects our relationships, New York 1980, Paulist Press.

Simmel G., Wymiana jako środek przezwyciężania czysto subiektywnego znaczenia wartości przedmiotu, in: P. Sztompka, M. Kucia, Socjologia Lektury, Kraków 2005, Wydawnictwo Znak, p. 72-89.

Singer I., Sex: A Philosophical Primer, Oxford 2001, Rowman \& Littlefield Publishers.

Slany K., Alternatywne formy życia małżeńsko-rodzinnego w ponowoczesnym świecie, Kraków 2002, Zakład Wydawniczy NOMOS.

Słownik Języka Polskiego, Wydawnictwo Naukowe PWN, http://sjp.pwn.pl/haslo.php?id=2483508 (20.06.2014).

Swidler A., Culture in Action: Symbols and Strategies, American Sociological Review 51, 1986.

Sztompka P., Zaufanie. Fundament społeczeństwa, Kraków 2007, Wydawnictwo Znak.

Weber M., Pojęcie działania społecznego, in: P. Sztompka, M. Kucia, Socjologia Lektury, Kraków 2005, Znak, p. 57-71.

Wojciszke B., Człowiek wśród ludzi. Zarys psychologii społecznej, Warszawa 2004, Wydawnictwo Naukowe Scholar.

Wouters C., Sex and Manners: Female emancipation in the West 1890-2000, London 2004, Sage. Zoldbrod A. P., Men, women, and infertility: intervention and treatment strategies, New York 1998, Lexington Books. 